\title{
EVALUASI SISTEM PENGENDALIAN INTERNAL ATAS SIKLUS PENGELUARAN KAS PADA BADAN USAHA MILIK DAERAH (STUDI PADA PDAM TIRTA MANAKARRA KABUPATEN MAMUJU)
}

\author{
Internal Control Systems Evaluation Of Cash Expenditure Cycle \\ On Regional Owned Enterprises \\ (Case Study PDAM Tirta Manakarra Kabupaten Mamuju)
}

\author{
Muh Ridwan Hayadin \\ Email: ridwanhayadin@gmail.com \\ STIE Muhammadiyah Mamuju
}

\begin{abstract}
ABSTRAK
PDAM Tirta Manakarra merupakan badan usaha milik daerah yang berlokasikan jalan Kurunggan Bassi Nomor 7 Kabupaten Mamuju, Sulawesi Barat. PDAM Tirta Manakarra berfokus pada bidang usaha yang menyediakan jasa layanan air minum dan air bersih kepada masyarakat umum. Penelitian ini, dilatar belakangi dengan hasil temuan audit di Tahun 2015 pada PDAM Tirta Manakarra tentang pengeluaran kas yang tidak sesuai peraturan. Penelitian ini bertujuan untuk mengevaluasi sistem pengendalian internal atas siklus pengeluaran kas berdasarkan lima komponen COSO, yakni: lingkungan pengendalian, penilaian risiko, aktivitas pengendalian, informasi dan komunikasi, serta monitoring. Penelitian ini dilakukan dengan cara membandingkan penerapan pengendalian internal atas siklus pengeluaran kas dengan pengendalian internal berdasarkan COSO, Penilaian pengendalian internal atas siklus pengeluaran kas PDAM Tirta Manakarra dibutuhkan data-data berupa: observasi, wawancara, dokumentasi, inspeksi dan konfirmasi. Hasil penelitian ini menunjukkan bahwa sistem pengendalian internal atas siklus pengeluaran kas pada lima komponen tidak efektif, sehingga perusahaan belum menunjang tujuan sistem pengendalian internal dalam aktivitas pengeluaran kas.
\end{abstract}

Kata Kunci : Pengendalian Internal, Pengeluaran Kas, BUMD, COSO

\section{ABSTRACT}

PDAM Tirta Manakarra is a regional owned enterprises that locations in Kurunggan Bassi street No. 7 Mamuju, West Celebes. PDAM Tirta Manakarra focuses on business sectors that provide drinking water and clean water to the general public. This study, against the background with the audit findings in 2015 at PDAM Tirta Manakarra of cash expenditures that do not fit the rules. This study aims to evaluate the system of internal control over cash expenditure cycle based on five components of COSO, namely: the control environment, risk assessment, control activities, information and communication, and monitoring. This research was conducted by comparing the application of internal control over cash expenditure cycle with internal controls based on COSO, assessment of internal control over cash disbursements cycle PDAM Tirta Manakarra required data in the form: observation, interviews, documentation, inspection and confir mation. These results indicate that the system of internal control over cash expenditure cycle on the five components are not effective, so companies do not support the internal control systems of interest in the activity of cash disbursements.

Keyword: Internal Control, cash expenditure, regional owned enterprises, COSO 


\section{PENDAHULUAN}

Sistem Pengendalian Internal (SPI) merupakan suatu alat yang berfungsi untuk mengawasi jalannya kegiatan perusahaan. Sistem pengendalian internal berdasarkan Peraturan Pemerintah Nomor 60 Tahun 2008 adalah proses integral dalam kegiatan yang dilakukan secara terus-menerus oleh pemimpin dan seluruh pegawai untuk memberikan keyakinan yang memadai atas tercapainya tujuan organisasi. Tujuan sistem pengendalian internal menurut Committee Of Sponsoring Organizations (COSO) memungkinkan suatu organisasi untuk mengembangkan dan menjaga sistem pengendalian internal secara efektif dan efisien yang kemudian dapat memperbesar kemungkinan atas pen-capaian tujuan entitas (Janvrin et al, 2012). Oleh karena itu, pengendalian yang baik dapat menjamin operasional berjalan dengan baik dan memberikan kinerja yang optimal sesuai dengan tujuan entitas. Adapun bentuk komponen-komponen pada pengendalian internal mulai dari lingkungan pengendalian, penilaian risiko, aktivitas pengendalian, informasi dan komunikasi serta pengawasan (COSO, 2013).

Badan Usaha Milik Daerah (BUMD) secara umum menurut Undang-Undang Nomor 5 Tahun 1962, Undang-Undang Nomor 32 Tahun 2004 dan Undang-Undang Nomor 23 Tahun 2014 tentang pemerintahan daerah bertujuan untuk memberikan manfaat bagi perkembangan perekonomian, kemanfaatan umum berupa penyedia barang atau jasa untuk pemenuhan hidup masyarakat sesuai kondisi, karakteristik, dan potensi daerah yang bersangkutan dengan tata kelola perusahaan yang baik dan memperoleh laba. Pada pasal 334 Undang-Undang Nomor 23 Tahun 2014 dijelaskan bahwa perusahaan daerah adalah BUMD yang seluruh modalnya dimiliki oleh satu daerah dan tidak terbagi atas saham. Modal tersebut diperoleh dari Anggaran Pendapatan Belanja Daerah (APBD).

Perusahaan Milik Daerah menerima subsidi dari Pemerintah Daerah sebagai pemilik modal sesuai dengan instruksi Peraturan Pemerintah Dalam Negeri Nomor 52 Tahun 2012 tentang Pedoman Pengelolaan Investasi Daerah. Pemerintah daerah dalam mengelola BUMD bertujuan untuk memperoleh profit yang disetor ke kas daerah sebagai Pendapatan Asli Daerah (PAD) dan dialokasikan untuk pembiayaan pembangunan daerah melalui basis APBD (Harahap, 2011).Kas merupakan komponen terpenting dalam kegiatan operasional perusahaan. Sebagian besar transaksi yang dilakukan perusahaan menggunakan kas. Kas dalam Pernyataan Standar Akuntansi Pemerintah Nomor 03 Tahun 2010 merupakan pe-menuhan kebutuhan dalam investasi yang harus diubah menjadi kas ke dalam jumlah yang dapat diketahui tanpa ada perubahan risiko nilai yang signifikan. Sifat kas yang liquid dan mudah digelapkan menjadikan pihak manajemen membentuk 
suatu sistem pengendalian internal terhadap kas dengan memisahkan fungsi-fungsi, penyimpanan, dan pencatatan. Perusahaan Daerah Air Minum (PDAM) Tirta Manakarra Kabupaten Mamuju merupakan BUMD yang bergerak pada usaha pelayanan air minum dan penyedia air bersih untuk masyarakat umum. Pelaksanaan operasional PDAM Tirta Manakarra melekat pada rangkaian kegiatan bisnis yang terkait dengan aktivitas siklus pengeluaran mulai dari permintaan pembelian, pemesanan, penerimaan, sampai pada pembayaran barang atau jasa (Romney et al, 2009). Adapun catatan pengeluaran kas pada laporan keuangan PDAM Tirta Manakarra 5 (lima) Tahun terakhir. Berikut pengeluaran kas PDAM Tirta Manakarra Kabupaten Mamuju pada laporan Keuangan Tahun 2011-2015 yang terlihat pada Tabel 1.

\section{Tabel 1.Pengeluaran Kas PDAM Tirta Manakarra Kabupaten Mamuju Tahun 2011-2015}

\begin{tabular}{ccc}
\hline NO & KETERANGAN & JUMLAH PENGELUARAN KAS \\
\hline $\mathbf{1}$ & Laporan Keuangan 2011 & Rp. 5.908 .808 .731 \\
$\mathbf{2}$ & Laporan Keuangan 2012 & Rp. 6.719 .078 .672 \\
$\mathbf{3}$ & Laporan Keuangan 2013 & Rp. 7.903 .248 .142 \\
$\mathbf{4}$ & Laporan Keuangan 2014 & Rp. 10.249.312.964 \\
$\mathbf{5}$ & Laporan Keuangan 2015 & Rp. 11.197.677.107 \\
\hline
\end{tabular}

Sumber:PDAM Tirta Manakarra (2016).

Tabel 1, menunjukkan adanya peningkatan pengeluaran kas pada PDAM Tirta Manakarra Kabupaten Mamuju yang meliputi laporan keuangan pada tahun 2011-2015. Menurut temuan audit, pengeluaran kas pada laporan keuangan Tahun 2013 sampai Tahun 2014 PDAM Tirta Manakarra mengalami kenaikan yang paling signifikan jumlahnya. Peningkatan yang signifikan disebabkan adanya pengeluaran kas yang berasal dari biaya kenaikan gaji karyawan yang tidak sesuai kebijakan, dan adanya pengeluaran kas terhadap biaya pensiun yang tidak sesuai dengan KepMendagri Otonomi Daerah Nomor 8 Tahun 2000 tentang Pedoman Akuntansi Perusahaan Daerah Air Minum. Peristiwa ini tentunya akan mendorong perusahaan untuk melakukan pengendalian internal pada pengeluaran kas untuk menjamin keamanan aset, keandalan laporan keuangan, kepatuhan peraturan, serta bentuk tindakan yang merugikan perusahaan.

Berdasarkan wawancara awal peneliti dengan pihak satuan pengawas internal (SPI) perusahaan, saat ini PDAM Tirta Manakarra masih memiliki kendala terhadap mekanisme pengendalian internal. Pihak SPI menyebutkan bahwa pedoman akuntansi yang diterapkan oleh 
PDAM Tirta Manakarra tidak sepenuhnya terlaksana. Hal ini, menyebabkan PDAM Tirta Manakarra melakukan transaksi pengeluaran kas yang tidak sesuai dengan Kepmendagri Otonomi Daerah Nomor 8 Tahun 2000 Tentang Pedoman Akuntansi Perusahaan Daerah Air Minum.

\section{Pengertian Pengendalian}

Definisi pengendalian internal menurut COSO di atas menjelaskan bahwa pengendalian internal me-rupakan suatu proses secara efektif dilakukan oleh dewan direksi, manajemen, dan personil lainya dalam sebuah entitas yang dirancang untuk memberikan keyakinan yang memadai tentang pencapaian tujuan yang berkaitan dengan operasi, pelaporan dan kepatuhan.

\section{Tujuan Pengendalian}

Menurut COSO (2013) dalam Irianto (2015), kerangka pengendalian internal memiliki tiga kategori tujuan sehingga memungkinkan suatu organisasi dapat fokus pada pengenaan aspek-aspek pengendalian internal yang berbeda.

a. Tujuan Operasional (Operations Objectives)

Tujuan ini berkaitan dengan efektivitas dan efisiensi operasi entitas, termasuk tujuan kinerja operasional dan financial, serta menjaga aset dari risiko hilang.

b. Tujuan Pelaporan (Reporting Objectives)

Tujuan ini berkaitan dengan pelaporan keuangan dan non keuangan, baik internal maupun eksternal dan dapat mencangkup keandalan, ketetapan waktu, transparansi atau persyaratan lain yang ditetapkan oleh regulator, diakui oleh pembuat standar atau kebijakan entitas.

c. Tujuan Kepatuhan (Compliance Objectives)

Tujuan ini berhubungan dengan kepatuhan terhadap hukum dan peraturan yang berlaku dalam entitas.

\section{Tujuan Pengendalian Internal Pada Pengeluaran kas}

Menurut Arens dan Loebbecke dalam Bawiling (2015), tujuan pengendalian internal atas pengeluaran kas adalah sebagai berikut.

1. Penggunaan dana yang lebih efektif,

2. Penyelenggaraan pengendalian untuk menjamin bahwa pembayaran hanya dilakukan dengan tujuan yang sesuai,

3. Membatasi jumlah pengendalian kas, artinya pengeluaran hanya dilakukan apabila telah mendapat persetujuan dari yang berwenang, 
4. Pencatatan harus dilakukan untuk setiap transaksi atas pengeluaran kas.

\section{Komponen Pengendalian Internal}

Terdapat lima komponen dalam kerangka pengendalian internal COSO, tidak jauh berbeda dengan PP Nomor 60 Tahun 2008, masing-masing berasal dari metode yang telah digunakan manajemen dalam menjalankan sebuah bisnis dan terintegrasi dalam proses manajemen. Kelima komponen pengendalian COSO (Committee of Spon-soring Organizations of the Treadway Commission) tersebut ialah :

1. Lingkungan pengendalian (Control Enviroment)

2. Aktivitas pengendalian (Control Activites)

3. Penilaian risiko (Risk Assesment)

4. Informasi dan komunikasi (Information and Communication)

5. Pengawasan (Monitoring)

\section{METODE PENELITIAN}

Jenis penelitian yang akan dilakukan merupakan studi kasus dengan pendekatan kualitatif deskriptif. Data yang dikumpulkan dengan teknik observasi, wawancara, inspeksi dokumen dan dokumentasi. Wawancara dilakukan secara langsung dengan berbagai karyawan yang memiliki peran besar pada perusahaan seperti: Direktur selaku pimpinan yang bertanggung jawab atas segala kegiatan yang terjadi pada perusahaan, bagian keuangan selaku yang bertanggung jawab terhadap pelaporan dan pengelolaan keuangan dan bagian satuan pengawas internal selaku yang bertanggung jawab atas kinerja manajemen sebuah organisasi.

Dari data yang telah dikumpulkan pada penelitian ini, data dianalisis dengan menggunakan teknik Miles dan Hubberman ialah reduksi data, penyajian data, dan kesimpulan/verifikasi.

Validitas data dilakukan bertujuan untuk mengukur ketepatan data yang diperoleh peneliti dari obyek penelitian. Penelitian ini, peneliti menggunakan uji credibility dalam mengukur ketepatan data dengan menggunakan teknik triangulasi. peneliti menggunakan metode triangulasi untuk menguji credibility data. Triangulasi yang digunakan peneliti adalah triangulasi teknik, dengan membandingkan data dari hasil observasi, wawancara, inspeksi dokumen, konfirmasi dan dokumentasi pada obyek penelitian. 


\section{HASIL DAN PEMBAHASAN}

\section{Analisis Pengendalian Internal Pengeluaran Kas.}

Menindaklanjut hasil temuan pemaparan atas penerapan sistem pengendalian internal atas siklus pengeluaran kas pada PDAM Tirta Manakarra mulai dari komponen lingkungan pengendalian, penilaian risiko, aktivitas pengendalian, informasi dan komunikasi, serta monitoring, yang merupakan modifikasi dari teori COSO. Berdasarkan hal tersebut, maka analisis kasus akan dipaparkan per unsur pengendalian internal sesuai dengan sistem pengendalian internal yang bertujuan untuk memberikan keyakinan memadai dalam tercapainya efektivitas dan efisiensi atas kehandalan pelaporan keuangan, pengamanan aset, dan ketaatan terhadap hukum dan peraturanperaturan.

\section{Lingkungan Pengendalian}

Lingkungan pengendalian merupakan komponen awal pada pengendalian internal yang mencangkup pada lingkungan organisasi. Berikut ini hasil evaluasi sistem pengendalian internal atas siklus pengeluaran kas pada komponen lingkungan pengendalian PDAM Tirta Manakarra berdasarkan observasi, wawancara, inspeksi dokumen, konfirmasi dan dokumentasi.

1. Prinsip menetapkan struktur, wewenang dan tanggung jawab.

Prinsip ini Direksi PDAM Tirta Manakarra Kabupaten Mamuju memiliki struktur organisasi yang mengatur tugas dan wewenang fungsi kerja kepada karyawan. Fungsi kerja tersebut diatur dalam Peraturan Bupati SK Nomor 188.45/179/KPTS/-III/2015 yang berisikan tentang adanya pembagian fungsi kerja karyawan atas pelaksanaan aktivitas transaksi pengeluaran kas yang diterapkan oleh Direksi mulai dari fungsi penyimpanan kas yang dilakukan oleh kepala bagian administrasi umum dan keuangan dan fungsi pencatatan yang dilakukan oleh urusan pembukuan. Tetapi, pada penerapan aktivitas untuk transaksi pengeluaran kas masih terdapat fungsi kerja yang memiliki dua fungsi (rangkap jabatan).

Berdasarkan uraian hasil analisis atas penerapan pengendalian internal dapat disimpulkan bahwa sistem pengendalian internal komponen lingkungan pengendalian pada PDAM Tirta Manakarra Kabupaten Mamuju belum efektif. Hal ini dilihat dari hasil temuan penelitian yang menunjukkan adanya ketidaksesuaian penerapan sistem pengendalian internal menurut prinsip Committee Of Sponsoring Organizations (COSO) dalam hal pembagian fungsi kerja atas pelaksanaan aktivitas 
pengeluaran kas, sehingga aktivitas transaksi pengeluaran kas dilakukan oleh satu fungsi yang dapat menyebabkan terjadinya risiko kehilangan kas.

\section{Penilaian Risiko}

Risiko merupakan suatu yang bersifat melekat dan tidak diinginkan serta dapat mendatangkan kerugian. Implementasi penilaian risiko bertujuan untuk mengidentifikasi dan menganalisis risiko yang relevan terhadap pencapaian tujuan organisasi dan menentukan langkah yang tepat dalam meminimalisasi risiko tersebut. Berikut ini hasil evaluasi sistem pengendalian internal atas siklus pengeluaran kas pada kom-ponen penilaian risiko PDAM Tirta Manakarra berdasarkan observasi, wawancara, inspeksi dokumen, konfirmasi dan dokumentasi.

1. Prinsip mengidentifikasi dan menganalisis risiko.

Pada prinsip ini Direksi PDAM Tirta Manakarra tidak mengidentifikasi dan menganalisis risiko yang terkait penyalahgunaan wewenang atas pengeluaran kas yang disebabkan adanya pelimpahan wewenang fungsi tugas bagi karyawan yang tidak hadir. Hal ini sangat berisiko terhadap kesalahan fungsi kerja dalam pelaksanaan aktivitas pengeluaran kas dan mengindikasi terjadinya penyalahgunaan fungsi yang berakibat pada kerugian yang disebabkan atas kecurangan. Selain itu, Direksi PDAM Tirta Manakarra tidak mengindentifikasi dan menganalisis risiko pengendalian internal atas dokumen pengeluaran kas, yang menyebabkan terjadinya risiko kerusakan fisik pada dokumen terkait pengeluaran, dan Direksi PDAM Tirta Manakarra tidak mengindentifikasi dan menganalisis risiko pengendalian internal atas penyalahgunaan kas yang akan mengakibatkan risiko kehilangan kas.

2. Prinsip mengidentifikasi dan menganalisis perubahan yang signifikan.

Prinsip ini Direksi PDAM Tirta Manakarra tidak menilai perubahan model atau prosedur atas aktivitas pengeluaran kas. Hal ini akan menyebabkan risiko pada aktivitas pelaksanaan proses pengeluaran kas yang tidak efisien dan efektif, yang disebabkan perusahaan tidak mengikuti perkembangan perubahan model dan prosedur siklus pengeluaran kas.

Berdasarkan uraian hasil analisis atas penerapan pengendalian internal dapat disimpulkan bahwa pengendalian internal komponen penilaian risiko pada PDAM Tirta Manakarra Kabupaten Mamuju belum efektif. Hal ini dapat dilihat dari hasil temuan penelitian yang menunjukkan adanya ketidaksesuaian penerapan sistem pengendalian internal terhadap temuan dalam prinsip Committee Of Sponsoring Organizations (COSO). 


\section{Aktivitas Pengendalian}

Aktivitas pengendalian merupa-kan rangkaian kegiatan berbentuk kebijakan-kebijakan, prosedur, teknik-teknik dan mekanisme yang digunakan untuk menjalankan arahan manajemen dalam pencapaian tujuan. Hasil evaluasi sistem pengendalian internal atas siklus pengeluaran kas pada komponen aktivitas pengendalian PDAM Tirta Manakarra berdasarkan hasil observasi, wawancara, inspeksi dokumen, konfirmasi dan dokumentasi.

1. Prinsip memilih dan mengembangkan kegiatan pengendalian.

Direksi PDAM Tirta Manakarra telah melakukan rotasi dan pemisahan fungsi kerja karyawan, tetapi pelaksanaan pemisahan fungsi kerja pada aktivitas pengeluaran kas masih terdapat rangkap jabatan yang disebabkan keterbatasan SDM. Hal ini akan mengindikasi terjadinya risiko kehilangan kas. Selain itu, Direksi PDAM Tirta Manakarra dalam melakukan rekonsiliasi atas pencocokan saldo transaksi pengeluaran kas tidak melibatkan fungsi satuan pengawas intern sebagai fungsi pengawasan atas aktivitas operasi. Hal ini akan mengindikasi terjadinya risiko kecurangan yang bersifat kolusi.

2. Prinsip memilih dan mengembangkan kegiatan pengendalian umum atas teknologi.

Direksi PDAM Tirta Manakarra tidak menggunakan sistem komputer untuk pencatatan voucher atas aktivitas transaksi pengeluaran kas. Hal ini dapat mengindikasi terjadinya risiko kerusakan atau kehilangan pada voucher pengeluaran kas, sehingga aktivitas pelaksanaan tidak efisien dan efektif.

3. Prinsip merinci ke dalam kebijakan dan prosedur.

Pada prinsip ini Direksi PDAM Tirta Manakarra tidak memiliki kebijakan dan prosedur yang mengatur pergantian wewenang dalam melakukan otorisasi pengeluaran kas. Hal ini akan mengindikasi terjadinya risiko kehilangan kas atas penyalahgunaan wewenang. Selain itu, Direksi PDAM Tirta Manakarra tidak memiliki kebijakan dan prosedur yang mengatur pergantian fungsi kerja karyawan yang tidak hadir. Hal ini akan mengindikasi terjadinya risiko kesalahan fungsi tugas yang tidak efektif atas aktivitas pengeluaran kas.

Berdasarkan uraian hasil analisis atas penerapan pengendalian internal dapat disimpulkan bahwa pengendalian internal pada komponen aktivitas pengendalian PDAM Tirta Manakarra Kabupaten Mamuju belum efektif. Hal ini dapat dilihat dari hasil temuan penelitian yang menunjukkan adanya ketidaksesuaian penerapan sistem pengendalian internal dalam prinsip Committee Of Sponsoring Organizations (COSO). 


\section{Informasi dan Komunikasi}

Informasi merupakan hasil olahan data yang kemudian digunakan sebagai pengambilan keputusan, sedangkan komunikasi adalah proses penyampaian berupa pesan atau informasi dengan menggunakan simbol, baik secara langsung ataupun tidak langsung dan mendapat umpan balik. Hasil evaluasi penerapan sistem pengendalian internal atas siklus pengeluaran kas pada komponen informasi dan komunikasi PDAM Tirta Manakarra berdasarkan hasil observasi, wawancara, inspeksi dokumen, konfirmasi dan dokumentasi.

1. Prinsip menggunakan informasi yang relevan.

Pada prinsip ini Direksi PDAM Tirta Manakarra tidak memiliki media sistem informasi akuntansi untuk melakukan proses transaksi pengeluaran kas. Hal ini akan berdampak pada ketidakefisienan aktivitas pengeluaran kas yang disebabkan tidak diterapkannya sistem media in-formasi untuk mempercepat dan menjamin keamanan data proses pengeluaran kas.

2. Prinsip komunikasi internal yang efektif.

Pada prinsip ini Direksi PDAM Tirta Manakarra tidak memiliki SOP tertulis khusus pada aktivitas pengeluaran kas. hal ini akan mengindikasi terjadinya risiko ketidakefektivan fungsi kerja pada proses pelaksanaan aktivitas pengeluaran kas.

Berdasarkan uraian hasil analisis atas penerapan pengendalian internal dapat disimpulkan bahwa pengendalian internal pada komponen informasi dan komunikasi PDAM Tirta Manakarra Kabupaten Mamuju belum efektif. Hal ini dapat dilihat dari hasil temuan penelitian yang menunjukkan adanya ketidaksesuaian penerapan sistem pengendalian internal dalam prinsip Committee Of Sponsoring Organizations (COSO).

\section{Monitoring}

Monitoring merupakan komponen terakhir dalam sistem pengendalian internal menurut COSO. Hasil evaluasi penerapan sistem pengendalian internal atas siklus pengeluaran kas komponen monitoring pada PDAM Tirta Manakarra berdasarkan hasil observasi, wawancara, inspeksi dokumen, konfirmasi dan dokumentasi.

1. Prinsip melakukan evaluasi berkelanjutan/terpisah.

Pada prinsip ini Direksi PDAM Tirta Manakarra melakukan evaluasi rutin atas pengeluaran kas setiap bulan yang dilakukan oleh SPI, tetapi SPI tidak membuat laporan tertulis. Hal ini akan mengindikasi terjadinya risiko pengulangan kesalahan yang disebabkan pihak SPI tidak melakukan tindaklanjut atas memaparkan hasil temuan-temuan kesalahan karyawan yang akan informasi kepada pimpinan sebagai bahan evaluasi atas kelemahan. selain itu, Direksi PDAM 
Tirta Manakarra memiliki audit internal sebagai fungsi pengawasan aktivitas operasi, tetapi fungsi audit internal tidak mengevaluasi fungsi kerja yang terkait pelaksanaan aktivitas pengeluaran kas secara berkala. Hal ini akan mengindikasi terjadinya risiko ketidakefektifan karyawan dalam fungsi kerja yang akan berdampak pada tindakan yang dapat merugikan perusahaan.

Berdasarkan uraian hasil analisis atas penerapan pengendalian internal dapat disimpulkan bahwa pengendalian internal pada komponen monitoring PDAM Tirta Manakarra Kabupaten Mamuju belum efektif. Hal ini dapat dilihat dari hasil temuan penelitian yang menunjukkan adanya ketidaksesuaian penerapan sistem pengendalian internal dalam prinsip Committee Of Sponsoring Organizations (COSO).

\section{Tujuan Pengendalian Internal Pengeluaran Kas}

Berikut ini merupakan hasil pembahasan atas paparan temuan analisis pengendalian internal yang telah diterapkan Direksi PDAM Tirta Manakarra Kabupaten Mamuju dalam pencapaian tujuan efektivitas dan efisiensi, keandalan pelaporan, pengamanan aset, serta ketaatan terhadap hukum dan peraturan-peraturan.

\section{Tujuan Efisiensi dan Efek-tivitas Pada Pengeluaran Kas}

Berikut ini hasil analisis dan paparan temuan atas tujuan efisiensi dan efektivitas pengeluaran kas terkait tujuan operasional pengendalian internal pengeluaran kas pada PDAM Tirta Manakarra Kabupaten Mamuju.

Pengendalian internal pada PDAM Tirta Manakarra dalam efisiensi dan efektivitas pengeluaran kas, Direksi belum menerapkan sistem voucher yang terkomputerisasi yang memastikan bukti voucher telah direkam dan aman, selain itu Direksi PDAM Tirta Manakarra belum menerapkan sistem informasi akuntansi berbasis komputer (data base), hal ini dikarenakan penggunaan sistem informasi akuntansi akan mempercepat proses aktivitas terhadap fungsi kerja, selain itu sistem informasi akuntansi penyimpanan dokumen transaksi pengeluaran kas pada data base akan lebih aman, sehingga pelaksanaan aktivitas pengeluaran kas lebih efisien dan efektif

Berdasarkan hasil analisis dan paparan temuan di atas, disimpulkan bahwa sistem pengendalian internal yang diterapkan oleh PDAM Tirta Manakarra Kabupaten Mamuju belum menunjang tercapainya efisiensi dan efektivitas pada pengeluaran kas. 


\section{Tujuan Pengamanan Aset Pada Pengeluaran Kas}

Berikut ini hasil analisis dan paparan temuan atas pencapaian tujuan perlindungan aset pengendalian internal pengeluaran kas pada PDAM Tirta Manakarra Kabupaten Mamuju.

Pengendalian perlindungan aset atas pengeluaran kas Direksi PDAM Tirta Manakarra dalam pelaksanaan aktivitas transaksi pengeluaran kas telah disajikan secara baik, hal ini didukung dengan pengendalian pengeluaran kas berupa penggunaan cek, voucher, kuitansi, jurnal pengeluaran kas besar dan kas kecil, serta formulir disposisi yang sesuai dengan peraturan Keputusan Menteri Dalam Negeri Otonomi Daerah Nomor 8 Tahun 2000 Tentang Pedoman Akuntansi Perusahaan Daerah Air Minum.

Berdasarkan hasil analisis dan paparan temuan di atas, disimpulkan bahwa sistem pengendalian internal yang diterapkan oleh PDAM Tirta Manakarra Kabupaten Mamuju telah menunjang tercapainya pengamanan aset terhadap pelaksanaan aktivitas pengeluaran kas.

\section{Tujuan Keandalan Pelaporan Pada Pengeluaran Kas}

Komponen pengendalian internal dilaksanakan secara efektif ketika menjamin terpenuhinya pen-capaian tujuan pengendalian internal pengeluaran kas yang dapat melahirkan relevansi terhadap pelaporan keuangan pengeluaran kas.

Pengendalian internal pada PDAM Tirta Manakarra dalam pelaksanaan aktivitas pengeluaran kas, Direksi belum memiliki SOP khusus pada aktivitas pelaksanaan pengeluaran kas sebagai acuan karyawan dalam menjalankan fungsi kerja, selain itu masih terdapat karyawan yang merangkap fungsi kerja pada pelaksanaan aktivitas pengeluaran kas, sehingga tidak mencerminkan keandalan pada pelaporan.

Berdasarkan hasil analisis dan paparan temuan di atas, disimpulkan bahwa sistem pengendalian internal yang diterapkan oleh PDAM Tirta Manakarra Kabupaten Mamuju belum menunjang tercapainya kehandalan pelaporan pada pengeluaran kas.

\section{Tujuan Ketaatan Hukum dan Peraturan Pada Pengeluaran Kas}

Berikut ini hasil analisis dan paparan temuan atas pencapaian tujuan kepatuhan pengendalian internal pengeluaran kas pada PDAM Tirta Manakarra Kabupaten Mamuju.

Pada penerapan struktur organisasi dan fungsi kerja (job descriptions) pada PDAM Tirta Manakarra, Direksi belum menaati sepenuhnya terkait SK Bupati Nomor 188.45/179/KPTS/III/2015 dan Peraturan Bupati Nomor 13 Tahun 2013 tentang struktur organisasi dan tata 
kerja perusahaan daerah air minum, hal ini dikarenakan masih terdapat karyawan yang menerapkan dua fungsi kerja yang berbeda, sehingga tidak mencerminkan kepatuhan terhadap peraturan. Selain itu, Direksi PDAM Tirta Manakarra dalam independensi atas aktivitas pelaksanaan pengeluaran kas belum menaati sepenuhnya, hal ini dikarenakan pihak Direksi tidak melibatkan fungsi kerja audit internal (satuan pengawas intern) dalam pengawasan pelaksanaan aktivitas pengeluaran kas dalam pencocokan saldo kas.

Berdasarkan uraian hasil analisis dan paparan temuan di atas, dapat disimpulkan bahwa sistem pengendalian internal yang diterapkan oleh PDAM Tirta Manakarra Kabupaten Mamuju belum dapat menunjang tercapainnya tujuan ketaatan hukum atas aktivitas pengeluaran kas.

\section{KESIMPULAN}

\section{Komponen Pengendalian Internal}

1. Lingkungan Pengendalian

PDAM Tirta Manakarra tidak memenuhi unsur lingkungan pengendalian yang efektif. Hal ini disebabkan Direksi tidak menjalankan Peraturan Bupati Nomor 13 Tahun 2013 yang mengatur pelaksanaan fungsi kerja (job description) terhadap aktivitas pengeluaran kas, se-ingga perusahaan tidak mencerminkan tata kelola yang baik.

2. Penilaian Risiko

PDAM Tirta Manakarra tidak memenuhi unsur penilaian risiko yang efektif. Hal ini disebabkan Direksi tidak mengidentifikasi dan menganalisis risiko terkait penyalahgunaan wewenang pada fungsi kerja bagi karyawan yang tidak hadir, kerusakan dan kehilangan dokumen pengeluaran kas, penyalahgunaan kas terhadap kebutuhan operasional di lapangan dan perubahan terhadap model dan prosedur atas aktivitas pengeluaran kas.

3. Aktivitas Pengendalian

PDAM Tirta Manakarra tidak memenuhi unsur aktivitas pengendalian yang efektif. Hal ini disebabkan Direksi mengalami keterbatasan SDM yang berdampak pada adanya rangkap jabatan terhadap fungsi kerja, fungsi audit internal yang tidak kompeten, sistem voucher pencatatan pengeluaran kas yang masih manual, dan tidak memiliki kebijakan dan prosedur yang mengatur pergantian wewenang atas otorisasi dan fungsi kerja.

4. Informasi dan Komunikasi

PDAM Tirta Manakarra tidak memenuhi unsur informasi dan komunikasi yang efektif. Hal ini disebabkan Direksi tidak memiliki media sistem informasi akuntansi untuk melakukan proses 
pelaksanaan aktivitas transaksi pengeluaran kas yang akan berdampak pada ketidakefisienan aktivitas pengeluaran kas, selain itu Direksi tidak memiliki standar operasional prosedur (SOP) khusus pada pelaksanaan aktivitas pengeluaran kas sebagai acuan karyawan terhadap fungsi kerja.

\section{Monitoring}

PDAM Tirta Manakarra tidak melaksanakan unsur pengawasan dengan efektif. Hal ini disebabkan fungsi audit internal perusahaan tidak membuat laporan tertulis terhadap temuan kesalahan atas pelaporan berdasarkan evaluasi berkala sebagai bahan pertimbangan kepada pimpinan perusahaan, selain itu audit internal tidak mengevaluasi fungsi kerja yang terkait pelaksanaan aktivitas pengeluaran kas secara berkala yang akan mengindikasi terjadinya risiko ketidakefektifan karyawan.

\section{Pencapaian Tujuan Pengendalian Internal}

1. Tujuan Efisiensi dan Efektivitas

Sistem pengendalian yang di-terapkan oleh PDAM Tirta Manakarra belum menunjang tercapainya tujuan efisiensi dan efektivitas. Hal ini dikarenakan Direksi belum menerapkan sistem voucher terkomputerisasi dan sistem informasi akuntansi berbasis komputer (data base), sehingga menyebabkan pelaksanaan aktivitas pengeluaran kas tidak efisien dan efektif.

2. Tujuan Pengamanan Aset atas Pengeluaran Kas

Sistem pengendalian yang diterapkan oleh PDAM Tirta Manakarra telah menunjang tercapainya tujuan pengamanan aset atas pengeluaran kas. Hal ini dikarenakan Direksi telah menerapkan pengendalian atas pengeluaran kas berupa penggunaan cek, voucher, kuitansi, jurnal pengeluaran kas besar, jurnal pengeluaran kas kecil, serta formulir disposisi, sehingga aktivitas ini memastikan pengamanan aset atas pengeluaran kas.

3. Tujuan Keandalan Pelaporan

Sistem pengendalian yang diterapkan oleh PDAM Tirta Manakarra belum menunjang tercapainya tujuan kehandalan pelaporan. Hal ini dikarenakan Direksi tidak memiliki standar operasional prosedur (SOP) khusus pengeluaran kas sebagai acuan kerja karyawan dan masih terdapat rangkap jabatan terhadap fungsi kerja, sehingga pelaksanaan aktivitas pengeluaran kas tidak mencerminkan keandalan pelaporan.

4. Tujuan Ketaatan Hukum dan Peraturan 
Sistem pengendalian yang di-terapkan oleh PDAM Tirta Manakarra belum menunjang tercapainya tujuan ketaatan hukum dan peraturan. Hal ini dikarenakan Direksi tidak mematuhi Peraturan Bupati Nomor 13 Tahun 2013 tentang struktur organisasi dan tata kerja perusahaan daerah air minum dan pihak Direksi tidak melibatkan fungsi kerja audit internal (satuan pengawas intern) dalam pengawasan pelaksanaan aktivitas pengeluaran kas dalam pencocokan saldo kas, sehingga tidak berjalannya kepatuhan terhadap hukum dan peraturan-peraturan.

\section{Rekomendasi}

Berikut ini adalah beberapa rekomendasi yang dapat disampaikan oleh penulis kepada Direksi PDAM Tirta Manakarra Kabupaten Mamuju atas penerapan sistem pengendalian internal atas pengeluaran kas.

1. Lingkungan Pengendalian

Direksi PDAM Tirta Manakarra agar lebih memperhatikan penerapan pelaksanaan fungsi kerja (job description) terhadap aktivitas pengeluaran kas sesuai Peraturan Bupati Nomor 13 Tahun 2013, sehingga dapat melahirkan tata kelola perusahaan yang baik.

2. Penilaian Risiko

Direksi PDAM Tirta Manakarra agar lebih cermat dalam me-lakukan identifikasi dan analisis terhadap risiko yang memungkinkan dapat menimbulkan kerugian bagi perusahaan berupa penyalahgunaan wewenang fungsi kerja, kerusakan dan kehilangan dokumen pengeluaran kas, penyalahgunaan kas, serta perubahan terhadap model dan prosedur yang terkait atas pelaksanaan aktivitas pengeluaran kas.

3. Aktivitas Pengendalian

Direksi PDAM Tirta Manakarra agar lebih meningkatkan aktivitas pengendalian dalam pembenahan sumber daya manusia (SDM) berupa perbaikan fungsi kerja untuk menghindari terjadinya rangkap jabatan dan terciptanya pengawasan kompeten, sistem voucher berbasis komputer, dan menyusun kebijakan dan prosedur yang mengatur pergantian wewenang fungsi kerja atas pelaksanaan aktivitas pengeluaran kas.

4. Informasi dan Komunikasi

Direksi PDAM Tirta Manakarra agar lebih meningkatkan sarana dan prasaran terhadap informasi dan komunikasi berupa membentuk standar operasional prosedur (SOP) khusus pengeluaran kas sebagai acuan kerja karyawan, selain itu penggunaan sistem informasi akuntansi berbasis komputer (data base). hal ini dilakukan untuk meningkat-kan efisien dan efektivitas atas pelaksanaan aktivitas pengeluaran kas. 


\section{Monitoring}

Direksi PDAM Tirta Manakarra agar lebih memperhatikan fungsi kerja audit internal sebagai fungsi pengawasan yang independen dalam menilai kinerja karyawan berdasarkan kepatuhan peraturan yang telah ditetapkan oleh perusahaan atas pelaksanaan aktivitas pengeluaran kas.

\section{DAFTAR PUSTAKA}

AICPA. 1949. Internal Control. Committe On Auditing Prosedure: United States Of America.

Badan Pemeriksa Keuangan dan Pembangunan Perwakilan Daerah Sulawesi Barat. 2015. Buku Laporan Hasil Evaluasi Kinerja PDAM Tirta Manakarra. Kabupa-ten Mamuju.

Bawiling, Cindy. 2015. Evaluasi Pe-nerapan Sistem Pengendalian Internal Pengeluaran Kas Pada Kantor Pengadilan Agama Tondano. Jurnal EMBA Vol.3 No.3 Sept. 2015, Hal.619-629.

Boyton, W. C., Johnson, R. N., Kell, W.G. 2006. Modern Auditing; Assurance Service and the Integrity of Financial Reporting, Eighth Edition, Von hoffmann Corporation. United States America

Committee of Sponsoring Organizations of the Treadway Commission (COSO). 2013. Internal Control-Integrated Framework. http://www.coso.org/IC.htm diakses tanggal 05 januari 2016.

Irianto, D. 2015. Eveluasi Efektivitas Sistem Pengendalian Internal Program Proyek Operasi Nasional Agraria pada Badan Pertanahan Nasional Kabupaten Bantul Yogyakarta. Tesis Program Magister Akuntansi Fakultas Ekonomika dan Bisnis Universitas Gadjah Mada.

Janvrin, D. J., E. A. P. Byrnes., G. P. Sschneider., and M. B. Curtis. 2012. The Updated COSO Internal Control-Integrated Framework: Rocommendations and Opportunities for Future Research, Journal of Information Systems, Vol. 26. Pp. 185-213.

Kementrian Dalam Negeri. 2012. Badan Usaha Milik Daerah. Jakarta: http://www.bpkp.go.id/puslitbangwas/konten/2291/14.125-Reviu-Literatur-Pengelolaan-BadanUsaha-Milik-Daerah diakses pada tanggal 16 September 2015.

Mulyadi. 2016. Sistem Akuntansi Buku 1 Edisi Keempat. Salemba Empat. Jakarta.

Pemerintah Indonesia. 1962. Pe-raturan Pemerintah Re-publik Indonesia Nomor 5 Tahun 1962 Tentang Pemerintah Daerah. Jakarta: Presiden Republik Indonesia.

Pemerintah Indonesia. 2000. Pe-raturan Pemerintah Re-publik Indonesia Nomor 8 Tahun 2000 Tentang Pe-doman Akuntansi Per-usahaan Daerah Air Minum. Jakarta: Presiden Republik Indonesia.

Pemerintah Indonesia. 2008. Pe-raturan Pemerintah Re-publik Indonesia Nomor 60 Tahun 2008 Tentang Sistem Pengendalian Pemerintah. Jakarta: Presiden Republik Indonesia. 
Pemerintah Indonesia. 2004. Peraturan Pemerintah Republik Indonesia Nomor 32 Tahun 2004 Tentang Pedoman Pengelolaan Investasi Daerah. Jakarta: Presiden Re-publik Indonesia.

Pemerintah Indonesia. 2010. Peraturan Pemerintah Republik Indonesia Nomor 71 Tahun 2010 Tentang Pernyataan Standar Akuntansi Pemerintah. Jakarta: Presiden Republik Indonesia.

Pemerintah Indonesia. 2012. Peraturan Pemerintah Republik Indonesia Nomor 52 Tahun 2012 Tentang Pemerintah Daerah. Jakarta: Presiden Republik Indonesia.

Pemerintah Indonesia. 2014. Pe-raturan Pemerintah Re-publik Indonesia Nomor 23 Tahun 2014 Tentang Pemerintah Daerah. Jakarta: Presiden Republik Indonesia.

Romney, M. B., \& Stainbart, P. J. 2009. Accounting Information System. New Jersey: Prentice Hall. 